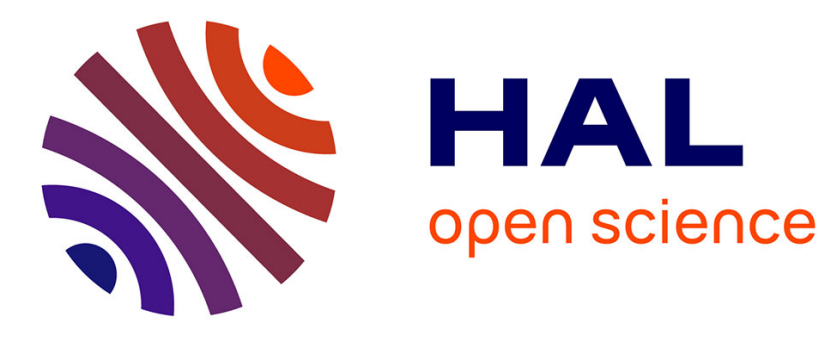

\title{
Renal Oncocytoma: An Algorithm for Diagnosis and Management
}

Maher Abdessater, Anthony Kanbar, Eva Comperat, Adrien Dupont-Athenor, Louise Alechinsky, Martin Mouton, Philippe Sebe

\section{- To cite this version:}

Maher Abdessater, Anthony Kanbar, Eva Comperat, Adrien Dupont-Athenor, Louise Alechinsky, et al.. Renal Oncocytoma: An Algorithm for Diagnosis and Management. Urology, 2020, 143, pp.173180. 10.1016/j.urology.2020.05.047 . hal-03013733

\section{HAL Id: hal-03013733 \\ https://hal.sorbonne-universite.fr/hal-03013733}

Submitted on 19 Nov 2020

HAL is a multi-disciplinary open access archive for the deposit and dissemination of scientific research documents, whether they are published or not. The documents may come from teaching and research institutions in France or abroad, or from public or private research centers.
L'archive ouverte pluridisciplinaire HAL, est destinée au dépôt et à la diffusion de documents scientifiques de niveau recherche, publiés ou non, émanant des établissements d'enseignement et de recherche français ou étrangers, des laboratoires publics ou privés. 


\title{
Renal Oncocytoma: An Algorithm for Diagnosis and Management
}

Maher Abdessater ${ }^{1,2}$, Anthony Kanbar ${ }^{1}$, Eva Comperat ${ }^{3}$, Adrien Dupont-Athenor ${ }^{2}$, Louise Alechinsky ${ }^{1,2}$, Martin Mouton ${ }^{2}$, and Philippe Sebe ${ }^{2}$

1- Department of Urology and Renal Transplantation, APHP - Pitié Salpetrière University Hospital, Paris, France

2- Department of Urology, Hospital Group Diaconesses Croix Saint-Simon, Paris, France

3- Department of Pathology, APHP - Tenon Hospital, Paris, France

\begin{abstract}
Renal oncocytoma is an uncommon tumor that exhibits numerous features which are characteristic but not necessarily unique. Percutaneous biopsy is a safe method of diagnosis. However, differentiation from other tumor subtypes often requires sophisticated analysis and is not universally feasible. This is why, surgical management can be considered as a first-line treatment or after surveillance. Potential triggers for change in management are: tumor size $>3$ $\mathrm{cm}$, stage progression, kinetics of size progression $(>5 \mathrm{~mm} / \mathrm{y})$, and clinical change in patient or tumor factors. Long-term follow-up data are lacking and greater centralization should be considered to reach adequate management.
\end{abstract}

\section{1- Introduction:}

In 1942, Zippel reported the first case of renal Oncocytoma (RO) [1]. This uncommon benign tumor of the renal parenchyma accounts for 3-7 \% of all solid renal masses [2]. When tumors of less than $4 \mathrm{~cm}$ are considered, its incidence increases to $18 \%$ [3]. The differentiation of RO from renal cell carcinoma (RCC) is challenging and imaging characteristics alone are unreliable. Histopathological diagnosis remains the reference standard. However, renal mass biopsy (RMB) prior to surgical intervention can be inconclusive [4]. In addition, the finding of RO on RMB does not exclude malignancy because some hybrid tumors associate chromophobe RCC and RO [5]. 
The aim of this article is to present a thorough literature review about RO, in order to elucidate the different aspects of this uncommon tumor. Based on this review, we will propose an algorithm for the diagnosis and the management of RO.

\section{2- Material and methods:}

This narrative review summarizes recent evidence on RO. We performed a search of the literature up to June 2019 using the Medline computerized database of the US National Library of Medicine, the Cochrane database, and Google Scholar. The search was carried out using the following Medical Subject Headings (MeSH) and free-text terms: Renal oncocytoma, small renal masses, and renal mass biopsy. The number of records identified was more than 500, which were limited to systematic reviews, randomized controlled trials, prospective nonrandomized studies, cohort, and retrospective non-randomized studies. The majority of these articles have been excluded at the first screening due to irrelevance or data duplicates and at the end, only fiftythree full-text articles were selected for a qualitative synthesis.

The PRISMA guidelines for the reporting of this study were used to perform an accurate research checklist and report.

\section{3- Results:}

\subsection{Clinical presentation}

Older patients (seventh decade of life) are mainly affected by RO. Up to 75\% of these patients are asymptomatic and their tumors are often incidentally discovered by imaging during a workup for other conditions. Symptoms which are found in about one third of patients include most 
commonly flank or abdominal pain and hematuria [3,6-8]. Uncommonly, a flank mass is palpable [6]. Occasionally, hypertension may be the presenting complaint and rare familial cases have been described, including patients diagnosed with Birt-Hogg-Dubé syndrome [9].

Differential diagnoses include other neoplasms with eosinophilic or oncocytic cytoplasm, primarily chromophobe RCC, clear-cell RCC with eosinophilic cytoplasm, oncocytic variant of papillary RCC and less commonly oncocytoid RCC occurring after neuroblastoma and epithelioid angiomyolipoma [10].

\subsection{Imaging}

Unfortunately, it is difficult to distinguish RO from RCC on the imaging appearance, and both usually end up resected. ROs appear as sharply demarcated lesions of variable size, but often are large at presentation [11]. Their typical tomographic images are described as homogeneous hypervascular masses with subsequent washout in the delayed phase. A central sharp stellate scar is seen in RO in one-third of cases, especially in large tumors. However, it can also be present in RCC [12]. Distinguishing features include the evidence of metastasis and/or aggressive infiltration of the adjacent structures, which strongly orient toward the diagnosis of RCC. In addition, up to $13 \%$ of patients have multiple $\mathrm{RO}$, and up to $32 \%$ have concurrent $\mathrm{RCC}$, this is why it is important to carefully evaluate both kidneys on imaging [13]. Main radiologic findings in renal oncocytoma are presented in Figure 1.

\subsubsection{Computed Tomography}

ROs are slightly hyperattenuating relative to the normal kidney parenchyma, on non-enhanced computed tomography (CT) images. However, on the nephrographic phase after contrast enhancement, they appear less attenuating than the renal parenchyma [14]. Tumors are 
homogeneous, well-encapsulated with clear margins and smooth contour. Their size range is from 3 to $10 \mathrm{~cm}$, and in symptomatic patients, the lesions are usually larger than $5 \mathrm{~cm}$ [15]. The already mentioned central hypoattenuating scar (called stellate scar) may be observed in 33\% of cases. This scar mimics the central necrosis commonly found in RCC and cannot be easily differentiated from it on $\mathrm{CT}$, despite the advances of multisection scanning and high-resolution thin sections through the kidneys [16].

Invasion or infiltration into the perinephric fat or vessels has been described in oncocytomas $[17,18]$ but regional lymphadenopathy and metastases are more typical findings of RCC. Occasionally calcification, necrosis, hemorrhage, and multifocal or bilateral tumors may be found. [19].

To help identify small RO, some studies have discussed the use of segmental enhancement inversion that is present when the renal oncocytoma is divided into 2 differently enhanced segments: there is a reversal of the relative degree of enhancement on the nephrographic phase images (120-180 seconds after contrast injection) compared to the corticomedullary phase images (30-40 seconds after contrast injection). Segmental enhancement inversion was mostly seen in oncocytomas smaller than $3 \mathrm{~cm}$, while central scars were more often present in oncocytomas larger than $2.5 \mathrm{~cm}[9,20]$.

In their study on 43 patients with $53 \mathrm{RO}$ and 123 patients with $128 \mathrm{RCC}$, Sasaguri et al used CT attenuation values and tumor texture (ie, heterogeneity and skewness) on biphasic contrastenhanced CT to differentiate oncocytomas from many subtypes of RCCs [15]. 
Pano et al. used 4-phase CT to differentiate between RCC and oncocytomas in 97 patients. They found that lesion size more than $4 \mathrm{~cm}$, the highest degree of lesion enhancement and its heterogeneity were the dominant features of RCC compared to RO [9].

\subsubsection{Magnetic Resonance Imaging}

ROs appear on magnetic resonance imaging (MRI) as well-defined and homogeneous masses, which are isointense to slightly hypointense when compared to the normal renal cortex on the non-enhanced T1 and T2 weighted sequences. However, slight T2 hyperintensity has also been reported [21]. When present, the stellate scar is hypointense on T1 and T2-weighted images. In contrast to CT imaging, MRI can differentiate the stellate scar from tumor necrosis. The latter appears hypointense on T1-weighted images and hyperintense on T2-weighted images and is a very important feature to rule out malignancy. Rarely, the central scar may appear bright on T2weighted images [22]. However, it does not show enhancement in the center of the homogenously enhanced oncocytoma after the intravenous administration of Gadolinium-based contrast [23].

Despite the high confidence degree with MRI for detecting RO, it does not make a specific diagnosis. Thus, differentiating oncocytoma from RCC is not always possible with an accuracy of $84 \%$, sensitivity of $90 \%$, and specificity of $63 \%[19,21,23]$.

\subsubsection{Nuclear Imaging}

The differentiation of benign renal oncocytomas from renal cell carcinomas seems very promising using ${ }^{99} \mathrm{Tc}$-sestamibi single-photon emission computed tomography (SPECT). Oncocytoma and hybrid oncocytoma/chromophobe tumors showed uptake of ${ }^{99} \mathrm{Tc}$-sestamibi in 
several studies, contrarily to other renal malignant tumors. RO with high fibrous component risk to be missed [24]. Exceptionally, some papillary tumors show sestamibi positivity that is much lower in intensity than oncocytoma or hybrid tumors. This imaging modality, showed a high true positive rate with a sensitivity of $96 \%$ and a specificity of $95.2 \%$, as reported by Tzortzakakis and Gorin. Although observation might be safe for hybrid tumors, which didn't show evidence of aggressiveness after 10 years of follow-up, it is not for papillary tumors. Additional quantitative tools to estimate accurately the biological behavior of tumors and to provide a secure diagnosis are needed $[24,25]$.

\subsection{Pathology}

\subsubsection{Gross description}

The gross appearance of RO is an important criterion. Tumors are well-circumscribed, unencapsulated, solid, homogenous with a brown amber cut surface similar to the normal renal parenchyma in color and different from the golden yellow cut surface of clear cell RCC where substantial hyalinization and fibrosis can also be present [2]. Five percent of RO are bilateral or multifocal and may invade renal capsule or renal vein. Twenty percent have gross hemorrhage but necrosis is rare [26]. As previously mentioned, the stellar scar is not specific for RO; it is not present in all tumors, and can also be found in chromophobe RCC and other slow-growing neoplasms [27]. RO size can range from small solid nodules to large masses mimicking highstage RCC [9].

\subsubsection{Microscopic description}

The architecture under microscope is highly variable. RO are composed of oncocytes which are large cells with an intensely eosinophilic granular cytoplasm. This aspect is the result of the presence of a big number of mitochondria, the absence of glycogen and the scant lipid content 
[28]. Mutations in the genome encoding nuclear and mitochondrial proteins, are believed to cause respiration defect with defective mitochondria, that normally should be removed by mitophagy, a selective form of autophagy. However, a defective autophagy is seen in RO, and is thought to produce benign instead of malignant tumors. It is attributed to metabolic-deficiencyinduced Golgi disassembly and lysosome dysfunction, blocking the activation of lysosomal protease [29].

Mainly, the tumors are made of lined patterns of uniform round or polygonal cells. They appear as nests with alveolar or tubular structures closely packed at the periphery and separated centrally, leading to their dispersion in the edematous myxoid or hyalinized stroma [28]. The presence of other patterns (such as highly compact nested architecture or small papillary structures protruding into cystic spaces), resulting in a more solid appearance, can raise the concern of an eosinophilic variant of papillary RCC, making the diagnosis uncertain [26]. Clear cytoplasm may also be focally present, typically in the area of the central scar. Nuclei are uniform, small, round and central with evenly dispersed chromatin and smooth contour. Occasional degenerative atypia (bizarre nuclear pleomorphism), focal vacuoles and areas of fibrosis may also be present [9]. Mitotic activity is extremely rare, and finding more than one readily identifiable mitotic figure is worrisome or potentially incompatible with the diagnosis [26].

Unusually, tumors have an "oncoblastic" appearance with small cells and a scanty cytoplasm. They have similar immunohistochemical and molecular features of usual oncocytomas regarding most of the markers [28]. 
Although a proximal tubular origin was suggested at the beginning, most pathologists suggest nowadays a distal tubular origin. Renal oncocytoma and chromophobe RCC are thought to be closely related, arising from intercalated cells $\alpha$ and $\beta$ respectively, with a subsequent divergent differentiation [28]. Main pathologic features of oncocytoma are presented in Figure 2.

\subsubsection{Immunohistochemistry}

The immunohistochemical profile of ROs show positivity for for CD117 (KIT), e-cadherin and S100A, and negativity to vimentin. Minimal staining is seen with cytokeratin 7 (CK7), contrarily to the stellar scars that exhibit increased staining. A new concept of low oncocytic tumor (LOT) has been described, where tumors look mostly like oncocytomas, but express positivity for CK7 and negativity for CD117. Nevertheless, those tumors are also benign without relapse or progression [30]. Another newly described entity is the concept of high-grade oncocytic (HOT) tumors, that show nested or tubular growth like the classical oncocytoma with uniform and large cells. They never show raisinoid-like (like chromophobe carcinoma) nuclei, but have predominant nucleoli (ISUP grade 3). They express normally CD117, but only half of them expresses CK7 [31].

\subsection{Renal Mass Biopsy}

Since $20-45 \%$ of SRM are benign, active surveillance could be a good option for most of them. This fact led to the increased use of RMB in the diagnosis of renal masses despite the controversy of this technique's diagnostic accuracy [32]. RMB has shown up to $80 \%$ diagnostic rate, with the ability to provide subtype and nuclear grade in the majority of the tumors [33]. However, this rate is lower in oncocytic lesions, as interpreting only a limited sampling of the lesion may not represent the entire tumor. Patel et al showed in their meta-analysis of 205 oncocytic RMB that the positive predictive value for oncocytoma diagnosis on RMB was $67 \%$ 
with significant heterogeneity and wide confidence interval, indicating that the diagnostic accuracy varies greatly between studies and therefore between pathologists [4].

The pathological similarity of RO with other oncocytic lesions created a split among urologic pathologists whether it is preferable, after RMB, to give an outright diagnosis of oncocytoma (with typical features on biopsy sample) or to use more general terminology, such as "oncocytic neoplasm" [26].

It is difficult to differentiate oncocytoma and RCC especially on limited samples. ROs usually don't show perinuclear halos, their cytoplasms are more uniformly granular, and they are nested with stromal edema [34]. As we already mentioned, immunohistochemical staining may also be helpful for differential diagnosis on RMB. Findings such as negative vimentin staining and positive KIT staining generally argue against papillary or clear cell RCC with eosinophilic cells [35]. Membranous positivity for KIT and negative staining for Vimentin is seen in both oncocytoma and chromophobe RCC. To differentiate those two tumors, other markers can be used, such as colloidal iron staining (Hale or modified Mowry) to better identify nuclear, stromal and cellular features $[36,37]$. Oncocytoma may show apical or weak focal fine cytoplasmic granules, compared to RCC that shows strong and diffuse microvacuolated cytoplasmic staining (Figure 2). However, those features might not be easily appreciated in small specimen biopsies, and some series showed variable staining of both tumors, which causes hesitation whether to base the treatment decisions on a biopsy sample or not [34]. Electron microscopy can also be useful and more cost effective than multiple immunohistochemical stains. Mostly, oncocytomas shows abundant mitochondria and absent or sparse microvesicles, while chromophobe RCC show numerous microvesicles and peripheral or abnormal mitochondria. 
RMB can facilitate appropriate management in patients who are candidates for nonsurgical treatment [35]. Though, the risk of selective sampling of the tumors and the probability of missing malignant sampling in hybrid tumors is not resolved yet [34].

Table 1 summarizes the main radiologic and pathologic features in favor of RO or RCC.

\subsection{Evolution}

The rate of benign findings after nephrectomy for small renal masses (SRM) has been as high as $21 \%$ to $34 \%[37,38]$. To avoid unnecessary surgeries for these benign tumors, studies have suggested RMB before definite treatment. However, concerning RO, the management remains controversial since the definitive diagnosis relies on careful microarchitectural examination and immunohistochemical evaluation that cannot be confirmed on biopsy most of the time [39]. Therefore, the need to better characterize the natural evolution of RO is crucial to potentially decrease the need for treatment.

The growth rate (GR) of RO was studied in many previous works. Kawaguchi et al reported a GR of $0.16 \mathrm{~mm}$ monthly or $0.20 \mathrm{~cm}$ annually for proven oncocytoma, and this finding was similar to the GR of other SRM [40]. Another meta-analysis showed a mean GR of $0.28 \mathrm{~cm}$ annually for SRMs followed up by imaging, with no statistically significant difference between RO and RCC [41]. The similarity in GR between RO and RCC was also shown in a Canadian prospective phase II clinical trial of active surveillance for SRMs [42]. Neuzillet et al, reported a mean GR of 0.7 and $2.4 \mathrm{~mm}$ annually for non-surgically and surgically treated RO respectively without identifying the predicting factors of positive growth that remain unclear so far. In addition, they noted that patients with RO treated non-operatively did not experience symptoms progression despite documented tumor growth on imaging [43]. A large-scale nephrectomy 
series showed that despite growing, the average size of benign tumors including RO was significantly smaller than that of RCC tumors [37,43].

Large tumors are not exclusively RCC since giant ROs have been reported through the literature [44]. Even when features of aggressiveness, perinephric fat or vascular invasion, are associated with RO those tumors have a non-malignant behavior and have excellent prognosis $[17,18]$. The metastatic progression is still virtually unknown [45].

\subsection{Management}

For many years, the standard treatment for RO has been surgical extirpation. Nephrectomy for both malignant and benign tumors has been associated with major complications. Hemorrhage into the collecting system, leak of urine, ureteral strictures and thermal injuries of adjacent bowels are known complications of surgical treatment [34]. A recent large retrospective national study in the United Kingdom on 1202 patients, showed that the complication rate associated with surgical removal of a renal oncocytoma was not negligible. Even though the majority had minimally invasive surgery, $20 \%$ developed in-hospital complications from which $18.9 \%$ were Clavien-Dindo grade 3 or above [46]. However, the recent advances in robotic-assisted surgeries, specifically in high-volume centers, are improving post-surgical outcomes by offering higher degrees of freedom of movements, dexterity and a 3D vision [47]. In fact, robotic partial nephrectomy has a significant positive effect on achieving better postoperative renal function and higher trifecta outcome, which is defined by warm ischemia time $\leq 25 \mathrm{~min}$, absence of positive surgical margin, and complications $\leq$ Clavien-Dindo grade 2 [47].

Given the benign nature of oncocytoma, surgical management may represent overtreatment in small renal oncocytomas that are asymptomatic [46]. The debate concerning the necessity of 
surgery for RO is continuous, especially with the increased practice of pre-treatment biopsy and the increasing knowledge of its indolent natural history, despite the occasional presence of apparently invasive features such as lymphovascular and renal capsular involvement $[17,18,45]$.

Tumor ablation was shown to be more cost-effective and safer than surgery for SRMs and could be an interesting alternative option [48].

Since the majority of RO has a slow annual GR, in well-selected patients active surveillance could be also a safe way for management [44]. Conservative management is especially beneficial in patients with multiple comorbidities, for whom renal function preservation is vital [33]. Active surveillance is even widely used in patients with small RCCs who are not candidates for surgery and it may be a safe management option for $\mathrm{T} 1$ oncocytomas confirmed on biopsy [41,45]. In this perspective, the European guidelines state that RO can be managed with active surveillance if a histological diagnosis has been attained [49]. However, a few concerns have been discussed concerning active surveillance. In fact, the coexistence of RCC and oncocytoma is seen in $10 \%$ to $32 \%$ of patients with RO [50,51]. This surprisingly high occurrence brings into question whether we should consider surgical management until more accurate methods become available to distinguish RO from RCC and to rule out the presence of coexistent malignant tumors.

Preoperative RMB has a positive predictive value of $67 \%$ for oncocytic lesions [4]. A systematic review of large-volume center series has reported a biopsy median diagnostic accuracy rate of 90.3\%. Those results show a beneficial role of RMB which might, in combination with other clinical assessment factors, help in the preoperative diagnosis and the subsequent prevention of the morbidity associated with overtreatment [52]. On the other hand, in a recent systematic review on RMB series, 11 of 46 cases initially diagnosed as oncocytic tumors on biopsy were 
found to be RCC after surgery, which makes surgical treatment regardless of the biopsy results, a good argument [5]. In order to improve the decision making concerning RO, a large single-center series (144 biopsied oncocytic tumors) suggested and used morphological features and expression markers that can aid in the distinction between RO and malignancy on RMB. The concordance between biopsy and final histology was 94\% [53].

\section{4- Conclusions}

Renal oncocytoma (RO) is an uncommon tumor that follows a benign course regardless of tumor size or degree of local invasiveness. It exhibits numerous features that are characteristic but not necessarily unique. Currently, only surgical resection with pathologic examination can reliably make the diagnosis.

Surgical treatment morbidity can be significant and if surgery is done, partial nephrectomy should be performed when technically possible, even for larger lesions.

Percutaneous biopsy is a safe diagnostic method that can redirect patients toward less morbid management options, including active surveillance or ablation, although differentiation from other tumor subtypes often requires sophisticated analysis and is not universally feasible.

Notwithstanding, long-term follow-up data are lacking and greater centralization for the work up and treatment of RO should be considered, to offer sufficient local expertise in making accurate diagnosis. This is why, reference centers are needed in order to develop a translational evaluation that can lead to adequate management. Finally, in recapitulation of our review and until the appearance of clear guidelines, we propose an algorithm for the diagnosis and management of renal oncocytomas (Figure 3). 
Table 1. Major radiologic and pathologic features in favor of renal oncocytoma or renal cell carcinoma.

\begin{tabular}{|c|c|c|}
\hline Diagnostic tools & Favor Renal Oncocytoma & Favor Renal Cell Carcinoma \\
\hline \multicolumn{3}{|c|}{ Imaging } \\
\hline Computed tomography (1) & $\begin{array}{l}\text { - Homogeneous } \\
\text { - Well-encapsulated with clear margins } \\
\text { - Stellate scar } \\
\text { - Spoken-wheel-like enhancement } \\
\text { - Segmental enhancement inversion }\end{array}$ & $\begin{array}{l}\text { - Lymph node enlargement } \\
\text { - Metastasis } \\
\text { - Heterogeneous enhancement } \\
\text { - Lower nodule enhancement in the } \\
\text { excretory phase in relation to the } \\
\text { unenhanced phase }\end{array}$ \\
\hline \multirow[t]{2}{*}{$\begin{array}{l}\text { Magnetic resonance } \\
\text { imaging }(2,3,4)\end{array}$} & $\begin{array}{l}\text { Tumor: } \\
\text { - Well-defined, homogeneous masse } \\
\text { - Isointense to slightly hypointense on } \\
\text { the non-enhanced T1 and T2 }\end{array}$ & $\begin{array}{l}\text { Tumor: } \\
\text { - Isointense on T1 } \\
\text { - Hyperintense on T2 } \\
\text { - Loss of signal intensity within the solid } \\
\text { portions of the tumor on opposed } \\
\text { phase images compared with in- } \\
\text { phase } \\
\text { - Cystic changes within the solid tumor } \\
\text { - Enhancement of viable component }\end{array}$ \\
\hline & $\begin{array}{l}\text { Stellate scar: } \\
\text { - Hypointense on T1 and T2 } \\
\text { - No enhancement in the center of the } \\
\text { homogenously enhanced oncocytoma }\end{array}$ & $\begin{array}{l}\text { Tumor necrosis: } \\
\text { - Hypointense on T1 } \\
\text { - Hyperintense on T2 } \\
\text { - No enhancement }\end{array}$ \\
\hline $\begin{array}{l}\text { Sestamibi nuclear imaging } \\
(5,6)\end{array}$ & - High uptake & - Negative or low uptake \\
\hline \multicolumn{3}{|c|}{ Pathology } \\
\hline Macroscopic appearance (7) & $\begin{array}{l}\text { - Brown amber cut surface similar to } \\
\text { the normal renal parenchyma in color }\end{array}$ & $\begin{array}{l}\text { - Golden yellow cut surface with } \\
\text { hyalinization and fibrosis }\end{array}$ \\
\hline Cytologic features (8) & $\begin{array}{l}\text { - Nuclei: round and regular membrane, } \\
\text { no perinuclear halos } \\
\text { - Cytoplasm: uniformly granular } \\
\text { - Architecture: nested with stromal } \\
\text { edema } \\
\text { - Entrapped normal tubules: present }\end{array}$ & $\begin{array}{l}\text { - Nuclei: pleomorphism, irregular } \\
\text { membrane, perinuclear clearing, } \\
\text { intranuclear pseudoinclusions } \\
\text { - Cytoplasm: heterogeneous texture } \\
\text { - Architecture: sheet-like or trabecular } \\
\text { pattern } \\
\text { - Entrapped normal tubules: absent }\end{array}$ \\
\hline Hale's colloidal iron stain (8) & $\begin{array}{l}\text { - Apical or weak focal fine cytoplasmic } \\
\text { granules }\end{array}$ & $\begin{array}{l}\text { - Strong, diffuse microvacuolated } \\
\text { cytoplasmic staining }\end{array}$ \\
\hline Electron microscopy (8) & $\begin{array}{l}\text { - Microvesicles: absent or sparse } \\
\text { - Mitochondria: abundant }\end{array}$ & $\begin{array}{l}\text { - Microvesicles: numerous } \\
\text { - Mitochondria: peripheral or abnormal }\end{array}$ \\
\hline Genome analysis (9) & $\begin{array}{l}\text { - Diploid pattern or near-diploid } \\
\text { aneuploidy }\end{array}$ & - Hypodiploid \\
\hline Immunohistochemistry (10) & $\begin{array}{l}\text { - KIT, e-cadherin, S100A + } \\
\text { - Vimentin - }\end{array}$ & $\begin{array}{l}\text { - KIT - } \\
\text { - Vimentin + }\end{array}$ \\
\hline
\end{tabular}

1. Alderman, M. A., Daignault, S., Wolf, J. S., Palapattu, G. S., Weizer, A. Z., Hafez, K. S., ... Wu, A. J. (2016). Categorizing renal oncocytic neoplasms on core needle biopsy: a morphologic and immunophenotypic study of 144 cases with clinical follow-up. Human Pathology, 55, 1-10. doi:10.1016/j.humpath.2016.03.017 
2. Pedrosa, I., Sun, M. R., Spencer, M., Genega, E. M., Olumi, A. F., Dewolf, W. C., \& Rofsky, N. M. (2008). MR Imaging of Renal Masses: Correlation with Findings at Surgery and Pathologic Analysis. RadioGraphics, 28(4), 985-1003. doi:10.1148/rg.284065018/

3. Pedrosa I, Sun MR, Spencer M, Genega EM, Olumi AF, Dewolf WC, et al. MR imaging of renal masses: Correlation with findings at surgery and pathologic analysis. Radiographics. 2008;28:985-1003.

4. Young JR, Coy H, Kim HJ, Douek M, Lo P, Pantuck AJ, et al. Performance of relative enhancement on multiphasic MRI for the Differentiation of Clear Cell Renal Cell Carcinoma (RCC) from Papillary and Chromophobe RCC subtypes and oncocytoma. Am J Roentgenol. American Roentgen Ray Society; 2017;208:812-9.

5. Tzortzakakis, A., Gustafsson, O., Karlsson, M., Ekström-Ehn, L., Ghaffarpour, R., \& Axelsson, R. (2017). Visual evaluation and differentiation of renal oncocytomas from renal cell carcinomas by means of $99 \mathrm{mTc}$-sestamibi SPECT/CT. EJNMMI Research, 7(1). doi:10.1186/s13550-017-0278-z

6. Gorin, M. A., Rowe, S. P., Baras, A. S., Solnes, L. B., Ball, M. W., Pierorazio, P. M., ... Allaf, M. E. (2016). Prospective Evaluation of 99mTc-sestamibi SPECT/CT for the Diagnosis of Renal Oncocytomas and Hybrid Oncocytic/Chromophobe Tumors. European Urology, 69(3), 413-416. doi:10.1016/j.eururo.2015.08.056

7. Moch H, Humphrey PA, Ulbright TM, Reuter VE. WHO Classification of Tumours of the Urinary System and Male Genital Organs. Fourth. Lyon: IARC; 2016.

8. Johnson, N. B., Johnson, M. M., Selig, M. K., \& Nielsen, G. P. (2010). Use of Electron Microscopy in Core Biopsy Diagnosis of Oncocytic Renal Tumors. Ultrastructural Pathology, 34(4), 189194. doi:10.3109/01913121003725713

9. Yusenko, M. V. (2010). Molecular pathology of renal oncocytoma: A review. International Journal of Urology, 17(7), 602-612. doi:10.1111/j.1442-2042.2010.02574.x

10.Wu, J., Zhu, Q., Zhu, W., Chen, W., \& Wang, S. (2015). Comparative study of CT appearances in renal oncocytoma and chromophobe renal cell carcinoma. Acta Radiologica, 57(4), 500506. doi:10.1177/0284185115585035 
Figure 1. Computed tomography characteristics seen frequently in renal oncocytoma.


(a) Contrast-enhanced CT image showing a well-defined round tumor less attenuating than normal parenchyma. (b) Contrast-enhanced CT image showing a stellate scar (white triangle) at the center of the tumor. (c, d) Contrastenhanced CT image showing segmental enhancement inversion of renal oncocytoma between nephrographic (black arrow) and corticomedullary (white arrow) phases. 
Figure 2. Histologic sections of renal oncocytoma and chromophobe renal cell carcinoma.
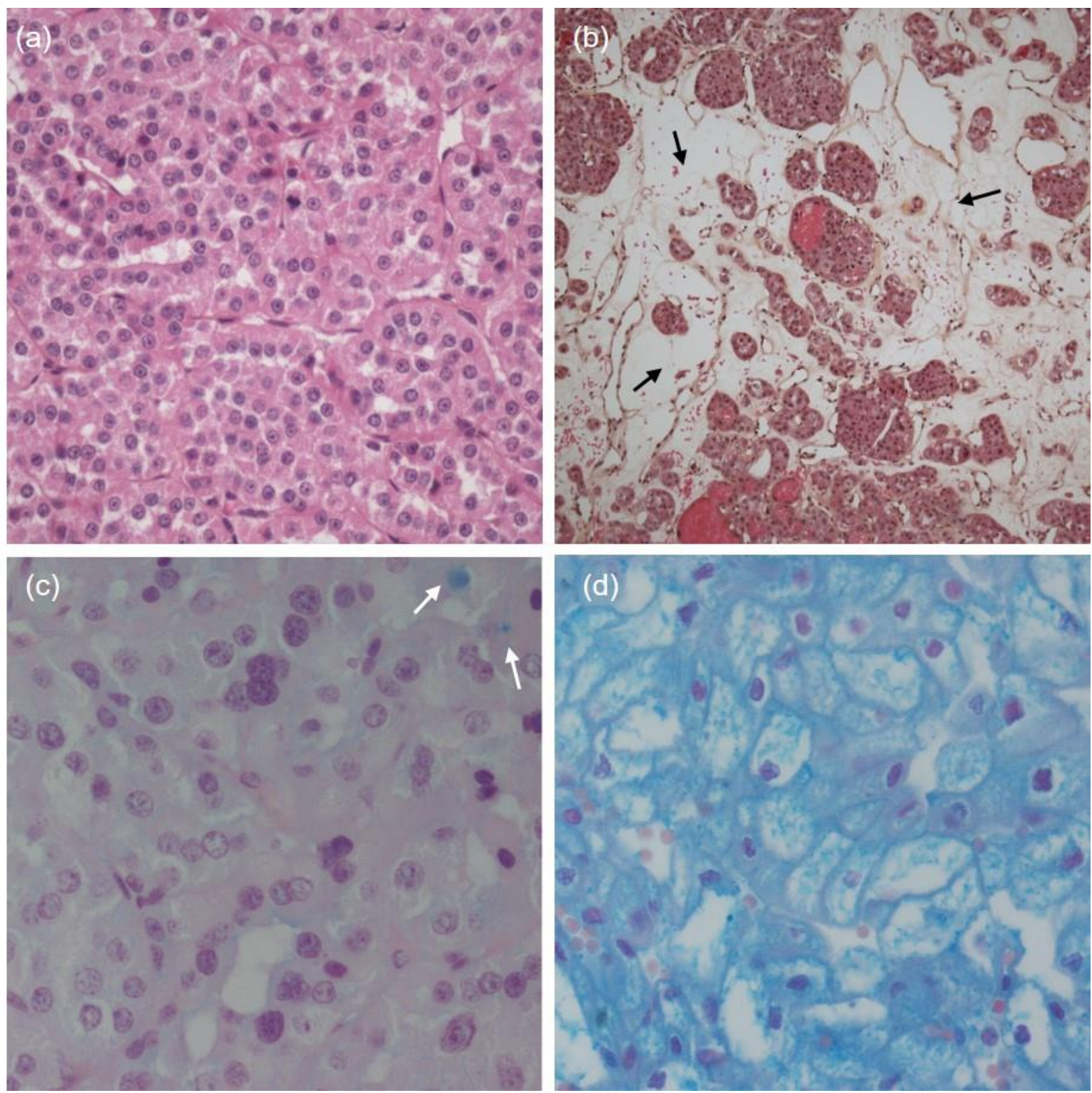

$(a, b, c)$ Renal oncocytoma showing eosinophilic, uniform cells with regular round nuclei with absence of mitosis and atypia. Cells show insular growth and are arranged in nests or in small islets divided by loose connective stroma (black arrows). Apical and weak staining pattern is visible with Hale's colloidal iron staining (white arrows). (d) Chromophobe renal cell carcinoma showing diffuse positivity for Hale's colloidal iron staining, with "raisinoid" nuclei having irregular contour. 
Figure 3. Algorithm for diagnosis and management of renal oncocytoma.

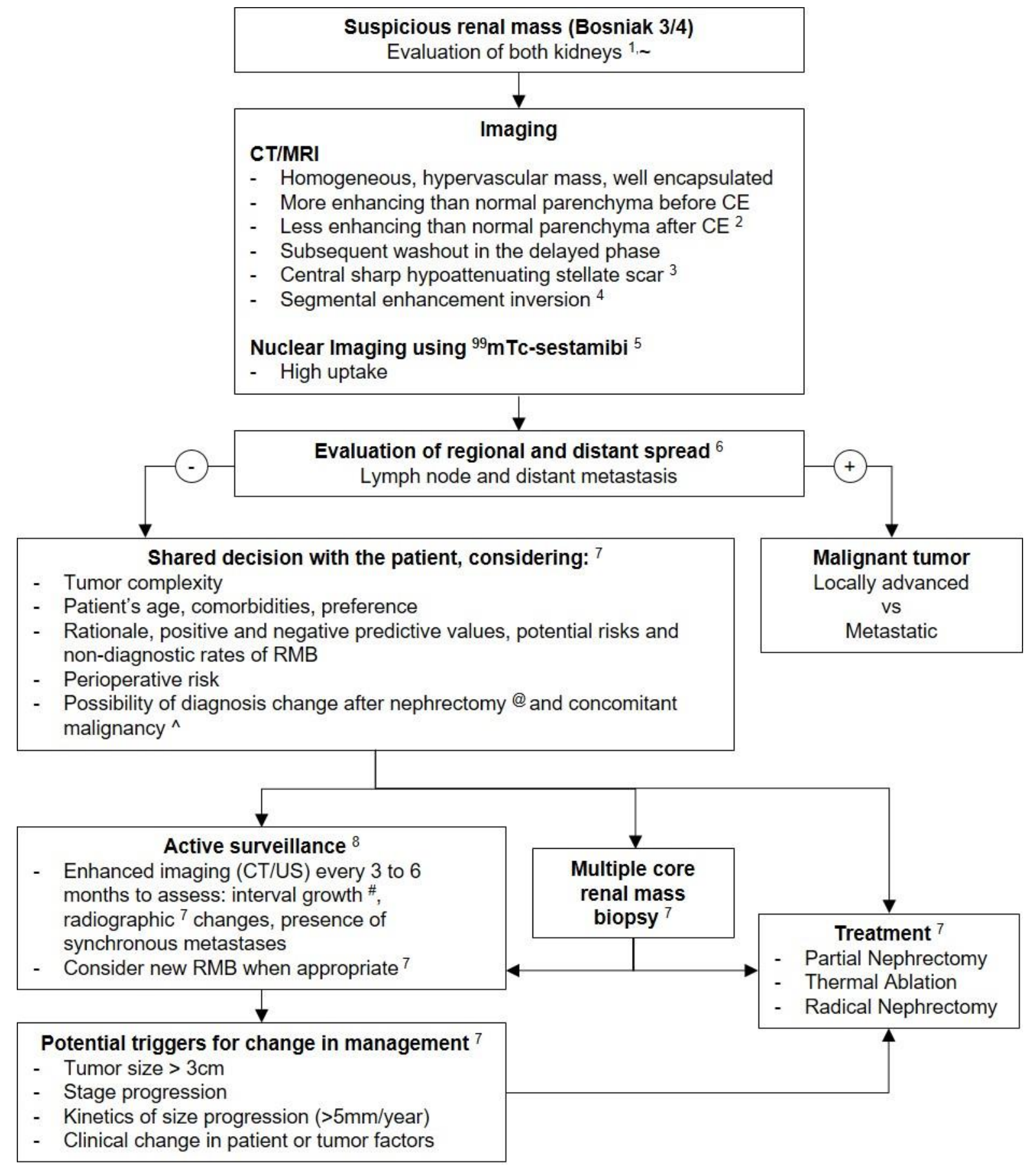

CT: computed tomography; MRI: magnetic resonance imaging; CE: contrast enhancement; Tc: technetium; US: ultrasonography

: $5 \%$ are bilateral or multifocal ${ }^{1}$

@ : Post-nephrectomy, renal cell carcinoma was diagnosed in $31.2 \%$ and other benign lesions were found in $4.2 \%{ }^{8}$

$\wedge$ : Concomitant renal cell carcinoma in $32 \%$ of cases ${ }^{9}$

\# : Majority of oncocytomas have slow progression $<14 \mathrm{~mm} /$ year $^{9}$

1. Williamson SR, Gadde R, Trpkov K, Hirsch MS, Srigley JR, Reuter VE, et al. Diagnostic criteria for oncocytic renal neoplasms: A survey of urologic pathologists. Hum Pathol. 2017. 63:149-56. 
2. Zokalj I, Marotti M, Kolarić B. Pretreatment differentiation of renal cell carcinoma subtypes by CT: the influence of different tumor enhancement measurement approaches. Int Urol Nephrol. 2014. 46 (6):1089-100

3. Mistry $\mathrm{R}$, Manikandan $\mathrm{R}$, Williams $\mathrm{P}$, et al. Implications of computer tomography measurement in the management of renal tumours. BMC Urol. 2008. 4. 8:13.

4. Alderman, M. A., Daignault, S., Wolf, J. S., Palapattu, G. S., Weizer, A. Z., Hafez, K. S., ... Wu, A. J. (2016). Categorizing renal oncocytic neoplasms on core needle biopsy: a morphologic and immunophenotypic study of 144 cases with clinical follow-up. Human Pathology, 55, 1-10. doi:10.1016/j.humpath.2016.03.017

5. Tzortzakakis, A., Gustafsson, O., Karlsson, M., Ekström-Ehn, L., Ghaffarpour, R., \& Axelsson, R. (2017). Visual evaluation and differentiation of renal oncocytomas from renal cell carcinomas by means of $99 \mathrm{mTc}$-sestamibi SPECT/CT. EJNMMI Research, 7(1). doi:10.1186/s13550-017-0278-z

6. Wu J, Zhu Q, Zhu W, Chen W, Wang S. Comparative study of CT appearances in renal oncocytoma and chromophobe renal cell carcinoma. Acta Radiol. 2015.13

7. Campbell S, Uzzo RG, Allaf ME, et al. Renal Mass and Localized Renal Cancer: AUA Guideline. J Urol. 2017;198(3):520-529. doi:10.1016/j.juro.2017.04.100

8. Ljungberg B, Albiges L, Bensalah K et al. EAU Guidelines on Renal Cell Carcinoma, 2017. Available at: http://uroweb.org/guideline/renal-cell-carcinoma.

9. Bird, V. G., Kanagarajah, P., Morillo, G., Caruso, D. J., Ayyathurai, R., Leveillee, R., \& Jorda, M. (2010). Differentiation of oncocytoma and renal cell carcinoma in small renal masses $(<4 \mathrm{~cm})$ : the role of 4 -phase computerized tomography. World Journal of Urology, 29(6), 787-792. doi:10.1007/s00345-010-0586-7 


\section{REFERENCES}

1. Zippel J. Zur Kenntnis der Onkocyten. Virchows Arch Pathol Anat Physiol Klin Med. 1941;308:36082.

2. Moch H, Humphrey PA, Ulbright TM, Reuter VE. WHO Classification of Tumours of the Urinary System and Male Genital Organs. Fourth. Lyon: IARC; 2016.

3. Bhatt NR, Davis NF, Flynn R, McDermott T, Thornhill JA, Manecksha RP. Dilemmas in diagnosis and natural history of renal oncocytoma and implications for management. J Can Urol Assoc. Canadian Medical Association; 2015;9:E709-12.

4. Patel HD, Druskin SC, Rowe SP, Pierorazio PM, Gorin MA, Allaf ME. Surgical histopathology for suspected oncocytoma on renal mass biopsy: a systematic review and meta-analysis. BJU Int. Blackwell Publishing Ltd; 2017. p. 661-6.

5. Hes O, Petersson F, Kuroda N, Hora M, Michal M. Renal hybrid oncocytic/chromophobe tumors - A review. Histol. Histopathol. 2013. p. 1257-64.

6. Gudbjartsson T, Hardarson S, Petursdottir V, Thoroddsen A, Magnusson J, Einarsson G V. Renal oncocytoma: a clinicopathological analysis of 45 consecutive cases. BJU Int. John Wiley \& Sons, Ltd; 2005;96:1275-9.

7. Benatiya MA, Rais G, Tahri M, Barki A, Sayegh H El, Iken A, et al. Renal oncocytoma: Experience of clinical urology a, urology department, chu ibn sina, rabat, morocco and literature review. Pan Afr Med J. African Field Epidemiology Network; 2012;12.

8. Romis L, Cindolo L, Patard JJ, Messina G, Altieri V, Salomon L, et al. Frequency, Clinical Presentation and Evolution of Renal Oncocytomas: Multicentric Experience from a European Database. 
Eur Urol. Elsevier B.V.; 2004;45:53-7.

9. Giunchi F, Fiorentino M, Vagnoni V, Capizzi E, Bertolo R, Porpiglia F, et al. Renal oncocytosis: A clinicopathological and cytogenetic study of 42 tumours occurring in 11 patients. Pathology. Elsevier B.V.; 2016;48:41-6.

10. Paño B, Macías N, Salvador R, Torres F, Buñesch L, Sebastià C, et al. Usefulness of MDCT to Differentiate Between Renal Cell Carcinoma and Oncocytoma: Development of a Predictive Model. Am J Roentgenol. American Roentgen Ray Society; 2016;206:764-74.

11. Schieda N, Al-Subhi M, Flood TA, El-Khodary M, McInnes MDF. Diagnostic accuracy of segmental enhancement inversion for the diagnosis of renal oncocytoma using biphasic computed tomography (CT) and multiphase contrast-enhanced magnetic resonance imaging (MRI). Eur Radiol. Springer Verlag; 2014;24:2787-94.

12. Cornelis F, Lasserre AS, Tourdias T, Deminière C, Ferrière JM, Le Bras Y, et al. Combined late gadolinium- enhanced and double-echo chemical-shift MRI help to differentiate renal oncocytomas with high central T2 signal intensity from renal cell carcinomas. Am J Roentgenol. 2013;200:830-8.

13. Sankineni S, Brown A, Cieciera M, Choyke PL, Turkbey B. Imaging of renal cell carcinoma. Urol. Oncol. Semin. Orig. Investig. Elsevier Inc.; 2016. p. 147-55.

14. Žokalj I, Marotti M, Kolarić B. Pretreatment differentiation of renal cell carcinoma subtypes by CT: The influence of different tumor enhancement measurement approaches. Int Urol Nephrol. Kluwer Academic Publishers; 2014;46:1089-100.

15. Sasaguri K, Takahashi N, Gomez-Cardona D, Leng S, Schmit GD, Carter RE, et al. Small ( $<4 \mathrm{~cm})$ renal mass: Differentiation of oncocytoma from renal cell carcinoma on biphasic contrast-enhanced CT. Am J Roentgenol. American Roentgen Ray Society; 2015;205:999-1007. 
16. Mistry R, Manikandan R, Williams P, Philip J, Littler P, Foster CS, et al. Implications of computer tomography measurement in the management of renal tumours. BMC Urol. 2008;8:13.

17. Williamson SR. Renal Oncocytoma with Perinephric Fat Invasion. Int. J. Surg. Pathol. SAGE Publications Inc.; 2016. p. 625-6.

18. Wobker SE, Przybycin CG, Sircar K, Epstein JI. Renal oncocytoma with vascular invasion: a series of 22 cases. Hum Pathol. W.B. Saunders; 2016;58:1-6.

19. Wu J, Zhu Q, Zhu W, Chen W, Wang S. Comparative study of CT appearances in renal oncocytoma and chromophobe renal cell carcinoma. Acta radiol. SAGE Publications Inc.; 2016;57:500-6.

20. Woo S, Cho JY, Kim SH, Kim SY, Lee HJ, Hwang S Il, et al. Segmental enhancement inversion of small renal oncocytoma: Differences in prevalence according to tumor size. Am J Roentgenol. 2013;200:1054-9.

21. Pedrosa I, Sun MR, Spencer M, Genega EM, Olumi AF, Dewolf WC, et al. MR imaging of renal masses: Correlation with findings at surgery and pathologic analysis. Radiographics. 2008;28:985-1003.

22. Prasad SR, Surabhi VR, Menias CO, Raut AA, Chintapalli KN. Benign renal neoplasms in adults: Cross-sectional imaging findings. Am. J. Roentgenol. 2008. p. 158-64.

23. Young JR, Coy H, Kim HJ, Douek M, Lo P, Pantuck AJ, et al. Performance of relative enhancement on multiphasic MRI for the Differentiation of Clear Cell Renal Cell Carcinoma (RCC) from Papillary and Chromophobe RCC subtypes and oncocytoma. Am J Roentgenol. American Roentgen Ray Society; 2017;208:812-9.

24. Tzortzakakis A, Gustafsson O, Karlsson M, Ekström-Ehn L, Ghaffarpour R, Axelsson R. Visual evaluation and differentiation of renal oncocytomas from renal cell carcinomas by means of 99mTcsestamibi SPECT/CT. EJNMMI Res. Springer Verlag; 2017;7:29. 
25. Gorin MA, Rowe SP, Baras AS, Solnes LB, Ball MW, Pierorazio PM, et al. Prospective Evaluation of 99mTc-sestamibi SPECT/CT for the Diagnosis of Renal Oncocytomas and Hybrid

Oncocytic/Chromophobe Tumors. Eur Urol. Elsevier B.V.; 2016;69:413-6.

26. Williamson SR, Gadde R, Trpkov K, Hirsch MS, Srigley JR, Reuter VE, et al. Diagnostic criteria for oncocytic renal neoplasms: a survey of urologic pathologists. Hum Pathol. W.B. Saunders; 2017;63:149_ 56.

27. Amin MB, Crotty TB, Tickoo SK, Farrow GM. Renal oncocytoma: A reappraisal of morphologic features with clinicopathologic findings in 80 cases. Am J Surg Pathol. 1997;21:1-12.

28. Yusenko M V. Molecular pathology of renal oncocytoma: A review. Int J Urol. John Wiley \& Sons, Ltd; 2010;17:602-12.

29. Joshi S, Tolkunov D, Aviv H, Hakimi AA, Yao M, Hsieh JJ, et al. The Genomic Landscape of Renal Oncocytoma Identifies a Metabolic Barrier to Tumorigenesis. Cell Rep. Elsevier B.V.; 2015;13:1895908.

30. Trpkov K, Williamson SR, Gao Y, Martinek P, Cheng L, Sangoi AR, et al. Low-grade oncocytic tumour of kidney (CD117-negative, cytokeratin 7-positive): a distinct entity? Histopathology. Blackwell Publishing Ltd; 2019;75:174-84.

31. He H, Trpkov K, Martinek P, Isikci OT, Maggi-Galuzzi C, Alaghehbandan R, et al. "High-grade oncocytic renal tumor": morphologic, immunohistochemical, and molecular genetic study of 14 cases. Virchows Arch. Springer Verlag; 2018;473:725-38.

32. Lane BR, Babineau D, Kattan MW, Novick AC, Gill IS, Zhou M, et al. A Preoperative Prognostic Nomogram for Solid Enhancing Renal Tumors $7 \mathrm{~cm}$ or Less Amenable to Partial Nephrectomy. J Urol. 2007;178:429-34. 
33. Leveridge MJ, Finelli A, Kachura JR, Evans A, Chung H, Shiff DA, et al. Outcomes of small renal mass needle core biopsy, nondiagnostic percutaneous biopsy, and the role of repeat biopsy. Eur Urol. $2011 ; 60: 578-84$.

34. Johnson NB, Johnson MM, Selig MK, Nielsen GP. Use of electron microscopy in core biopsy diagnosis of oncocytic renal tumors. Ultrastruct Pathol. 2010;34:189-94.

35. Richard PO, Jewett MAS, Bhatt JR, Evans AJ, Timilsina N, Finelli A. Active Surveillance for Renal Neoplasms with Oncocytic Features is Safe. J Urol. Elsevier Inc.; 2016. p. 581-7.

36. Ng KL, Rajandram R, Morais C, Yap NY, Samaratunga H, Gobe GC, et al. Differentiation of oncocytoma from chromophobe renal cell carcinoma (RCC): Can novel molecular biomarkers help solve an old problem? J. Clin. Pathol. 2014. p. 97-104.

37. Zhao W, Tian B, Wu C, Peng Y, Wang H, Gu WL, et al. DOG1, cyclin D1, CK7, CD117 and vimentin are useful immunohistochemical markers in distinguishing chromophobe renal cell carcinoma from clear cell renal cell carcinoma and renal oncocytoma. Pathol Res Pract. Elsevier GmbH; $2015 ; 211: 303-7$.

38. Gill IS, Kavoussi LR, Lane BR, Blute ML, Babineau D, Colombo JR, et al. Comparison of 1,800 Laparoscopic and Open Partial Nephrectomies for Single Renal Tumors. J Urol. 2007;178:41-6.

39. Volpe A, Kachura JR, Geddie WR, Evans AJ, Gharajeh A, Saravanan A, et al. Techniques, Safety and Accuracy of Sampling of Renal Tumors by Fine Needle Aspiration and Core Biopsy. J. Urol. 2007. p. $379-86$.

40. Kawaguchi S, Fernandes KA, Finelli A, Robinette M, Fleshner N, Jewett MAS. Most renal oncocytomas appear to grow: Observations of tumor kinetics with active surveillance. J Urol. 2011;186:1218-22. 
41. Chawla SN, Crispen PL, Hanlon AL, Greenberg RE, Chen DYT, Uzzo RG. The natural history of observed enhancing renal masses: Meta-analysis and review of the world literature. J Urol. Elsevier Inc.; $2006 ; 175: 425-31$.

42. Jewett MAS, Mattar K, Basiuk J, Morash CG, Pautler SE, Siemens DR, et al. Active surveillance of small renal masses: Progression patterns of early stage kidney cancer. Eur Urol. 2011;60:39-44.

43. Neuzillet Y, Lechevallier E, Andre M, Daniel L, Nahon O, Coulange C. Follow-up of renal oncocytoma diagnosed by percutaneous tumor biopsy. Urology. 2005;66:1181-5.

44. Banks KL., Cherullo EE, Novick AC. Giant renal oncocytoma. Urology. 2001;57:365.

45. Liu S, Lee S, Rashid P, Bangash H, Hamid A, Lau J, et al. Active surveillance is suitable for intermediate term follow-up of renal oncocytoma diagnosed by percutaneous core biopsy. BJU Int. Blackwell Publishing Ltd; 2016;118:30-4.

46. Neves JB, Withington J, Fowler S, Patki P, Barod R, Mumtaz F, et al. Contemporary surgical management of renal oncocytoma: a nation's outcome. BJU Int. Blackwell Publishing Ltd; 2018;121:893-9.

47. Carneiro A, Sivaraman A, Sanchez-Salas R, Di Trapani E, Barret E, Rozet F, et al. Evolution from laparoscopic to robotic nephron sparing surgery: a high-volume laparoscopic center experience on achieving ‘trifecta' outcomes. World J Urol. Springer Verlag; 2015;33:2039-44.

48. Larcher A, Sun M, Dell'Oglio P, Trudeau V, Boehm K, Schiffmann J, et al. Mortality, morbidity and healthcare expenditures after local tumour ablation or partial nephrectomy for T1A kidney cancer. Eur J Surg Oncol. W.B. Saunders Ltd; 2017;43:815-22.

49. Ljungberg B, Albiges L, Bensalah K, Bex A, Giles R., Hora M, et al. EAU Guidelines on Renal Cell Carcinoma [Internet]. 2019 [cited 2020 Mar 25]. Available from: https://uroweb.org/guideline/renal-cell- 
carcinoma/

50. Licht MR, Novick AC, Tubbs RR, Klein EA, Levin HS, Streem SB. Renal oncocytoma: clinical and biological correlates. J Urol. 1993;150:1380-3.

51. Dechet CB, Bostwick DG, Blute ML, Bryant SC, Zincke H. Renal oncocytoma: Multifocality, bilateralism, metachronous tumor development and coexistent renal cell carcinoma. J Urol. Lippincott Williams and Wilkins; 1999;162:40-2.

52. Marconi L, Dabestani S, Lam TB, Hofmann F, Stewart F, Norrie J, et al. Systematic review and metaanalysis of diagnostic accuracy of percutaneous renal tumour biopsy. Eur. Urol. Elsevier B.V.; 2016. p. 660-73.

53. Alderman MA, Daignault S, Wolf JS, Palapattu GS, Weizer AZ, Hafez KS, et al. Categorizing renal oncocytic neoplasms on core needle biopsy: A morphologic and immunophenotypic study of 144 cases with clinical follow-up. Hum Pathol. W.B. Saunders; 2016;55:1-10. 